Avrupa Bilim ve Teknoloji Dergisi

Sayı 33, S. 119-125, Ocak 2022

(C) Telif hakkı EJOSAT'a aittir

Arastırma Makalesi
European Journal of Science and Technology

No. 33, pp. 119-125, January 2022

Copyright C 2022 EJOSAT

Research Article

\title{
Karar Kuramı ve Karar Verme
}

\author{
Sena Güngör ${ }^{1 *}$, Uğur Özcan ${ }^{2}$

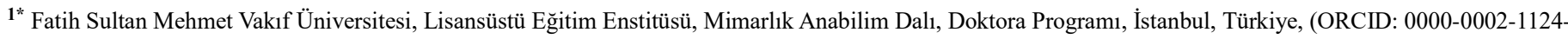 \\ 2385), sena.gngr.52@gmail.com \\ 2 Fatih Sultan Mehmet Vakıf Üniversitesi, Mimarlık ve Tasarım Fakültesi, Mimarlık Bölümü, İstanbul, Türkiye (ORCID: 0000-0003-0002-4478), uozcan@,fsm.edu.tr
}

(İlk Geliş Tarihi 12 Aralık 2021 ve Kabul Tarihi 25 Ocak 2022)

(DOI: $10.31590 /$ ejosat.1035682)

ATIF/REFERENCE: Güngör, S. \& Özcan, U. (2022). Karar Kuramı ve Karar Verme. Avrupa Bilim ve Teknoloji Dergisi, (33), 119125 .

$\ddot{\mathbf{O z z}}$

Yaşamın hemen her aşamasında, yapılmakta olan veya yapılması planlanan çeşitli eylem ve olaylar ile ilgili çok sayıda alternatif arasından seçim yapmayı gerektiren durum veya problemlerle karşı karşıya kalınabilmektedir. Bu durum ve problemler, insanları çözüm bulmaya yöneltmekte; başka bir ifadeyle, seçim yapmaya zorlamaktadır. Birden fazla alternatifin oluşması durumuyla başlayan seçim süreci, belirli ölçütler çerçevesinde hedefe ulaştıran alternatiflerden bir veya birkaçının seçilmesiyle sonlanmaktadır. Bu seçim işlemi, "karar verme" eylemini en basit şekilde tanımlamaktadır. Karar verme, insan yaşamıyla oldukça iç içe geçmiş bir eylemdir. İnsanlar, zaman zaman farkında olmaksızın, istemsiz olarak karar vermektedir. Ancak, verilmesi gereken kararlar, her zaman basit, rutin, belirlilik içeren, üzerinde fazla düşünmeyi gerektirmeyen ve çözümlenmesi kolay olan türden olmayabilir. Bazı kararlar ise, çok daha karmaşık, belirsizlik içeren ve yüksek risk taşıyan yapıdadır. Bu noktada, yönetim bilimlerinin en önemli unsurlarından biri olan "karar verme”"nin yönetsel süreçler için vazgeçilmez bir hale gelmesiyle birlikte karar verme yaklaşımları ortaya çıkmıştır. Bu çalışma, yaşamın tüm alanlarını derinden etkileyen "karar verme”" kavramının önemini ortaya koymak amacıyla yapılmıştır.

Anahtar Kelimeler: Karar kuramı, Karar verme eylemi, Karar verme süreci.

\section{Decision Theory and Decision-Making}

\begin{abstract}
In almost every stage of life, individuals may be faced with situations or problems that require choosing among many alternatives. These situations and problems lead individuals to find solutions; in other words, it forces them to choose. The selection process, which starts with the formation of more than one alternative, ends with the selection of one of the alternatives that reach the target within the framework of certain criteria. This selection process most simply describes the "decision-making". Decision making is an action that is highly intertwined with individual's life. Individuals often make decisions unconsciously and involuntarily. However, some decisions are not always simple, routine, specific or easy to resolve. On the other hand, some decisions are much more complex, uncertain or carry high-risk. At this point, with the "decision-making" which is one of the most important elements of the management science, becoming indispensable for managerial processes, decision-making approaches have emerged. This study was carried out in order to reveal the importance of the concept of "decision making", which deeply affects all areas of life.
\end{abstract}

Keywords: Decision-making theory, Decision-making, Decision-making process.

\footnotetext{
*Sorumlu Yazar: sena.gngr.52@gmail.com
} 


\section{Giriş}

İnsanlık tarihi ile birlikte başlayan yönetsel faaliyetler, örgütsel yapının belirli amaçlar doğrultusunda belirli işleri gerçekleştirme çabalarının olduğu tüm alanlarda söz konusu olmuştur. En eski yönetsel faaliyetler, toplumların yönetiminde uygulanmış ve bununla ilintili olarak savunma örgütlerinde meydana gelmiş, ekonomi alanında yönetsel faaliyetler ise sonraki dönemlerde gelişmiştir. 1950'li yılların sonuna kadar yönetim kavramı, dar anlamda, günlük işlerin basit bir şekilde yürütülmesi olarak kabul edilmiştir. 18.yy'ın ikinci yarısından sonra, endüstri devrimi sonrasında içerisinde bulunulan çevrede meydana değişim ve gelişimlere uyum sağlama zorunluluğuna bağlı olarak, yönetim alanında yapılan çalışmalar artış göstermiştir. Böylece, yönetim, ayrı bir bilim olmaktan çıkarak, ekonomi, siyaset, hukuk, sosyoloji, psikoloji, tarih, matematik gibi çeşitli alanla etkileşim içerisinde olan bir bilim haline gelmiştir. Buna göre, yönetimin, en eski bilimlerden biri olduğunu söylemek mümkündür. 20.yy’ın ilk çeyreğinde, "bilimsel yönetim yaklaşımı", ikinci çeyreğinde ise, "insan ilişkileri yaklaşımı" hâkim olmuştur. 1930'lu yıllara kadar egemen olan bilimsel yönetim yaklaşımında; örgüt bir makine, örgütteki insanlar ise, bu makinenin dişlileri olarak ele alınmıştır. Bilimsel yönetim yaklaşımındaki makineleşme yerine insan unsurunu ön plana çıkaran ve insanı sosyal bir varlık olarak ele alan "insan ilişkileri yaklaşımı” ortaya çıkmıştır. Bu yaklaşım, örgütsel yapı içerisindeki iletişim ve ilişkilerin verimliliği doğrudan etkilediğini savunmaktadır. $\mathrm{Bu}$ iki yaklaşımı ile birlikte zenginleşen yönetim biliminde yeni kuramlar geliştirilmiştir. Bunlar; Karar (Verme) Kuramı, Sistem Kuramı ve Durumsallık Kuramı'dır.

Karar Kuramı, kendi içerisinde Klasik Rasyonel ve Sınırlı Rasyonel Karar Kuramı olarak iki gruba ayrılmaktadır. Klasik Rasyonel Karar Kuramı, karar vericinin olabilecek tüm alternatifleri ve sonuçlarını bilerek hareket ettiğini ve optimal kararlar verdiğini kabul etmektedir. Bu yaklaşıma göre, karar verici, çıkarlarını ön planda tutarak rasyonel seçimler yapmaktadır.

Klasik Rasyonel Karar Kuramı'nın idealize edilmiş koşullarını eleştiren Herbert Alexander Simon, Sınırlı Rasyonel Karar Kuramı'nı ortaya koymuştur. Simon (1965), "karar verme" ile "yönetme" eylemlerinin eş anlamlı olduğunu ifade etmektedir. Simon'un yaklaşıma göre, insanın belirli bir hedefe ulaşabilmek için bilinçli olarak bir yolu seçmesi olarak tanımlanan karar verme, örgütlemenin temel süreci; karar ise yönetimin amacı olarak ele alınmaktadır. Simon'un yaklaşımının temeli karar verme, karar vermenin dayanağı da doyum olgusudur. Simon'a göre, karar vericiler örgütsel, çevresel ya da içsel sınırlılıklar sebebiyle rasyonel olamazlar. Klasik Rasyonel Karar Kuramı'ndaki rasyonel karar vericinin yerini, koşulların getirdiği tüm gerçeklik ve sınırlılıkları benimseyen yönetsel bir karar verici almaktadır. Örgüt içerisinde, insanın davranışlarını sınırlandıran birtakım etmenler bulunmasına karşın, karar verici, amaç gözetici veya doyum arayıcı şekilde davranışlar göstermektedir. Belirli bir hedefe yönelen karar verici, bu hedefi gerçekleştirecek belirli yolları takip etmekte ve birden fazla yolla karşılaştığında ise, en uygun olanı ya da en çok doyum vereni benimsemektedir. Karar verici, doyum sağlayan kararlar vererek en tatmin edici sonuçları ortaya koymaktadır.

\section{Karar Verme}

İnsanlar, günlük yaşam içerisinde, pek çok konuda çeşitli kararlar vermektedir. Verilen kararlar, içerik ve önem açısından birbirinden farkl1lıklar gösterseler de ortak bir paydada buluşmaktadır. Söz konusu ortak payda, karar vericinin, her durumda karar alternatiflerini belirlemesi ve hangi alternatifin hedefe ulaşmada en uygun yol olduğuna karar vermesidir. Karar, karşı karşıya kalınan çok sayıdaki alternatif içerisinden yapılan seçimlerin genel bir ifadesidir. Karşılaşılan durumda, birden fazla ölçüt ve alternatif olduğunda, bir karar probleminin varlığı söz konusudur.

Karar kelimesi, "aralarında bir seçme yapma zorunluluğu olan olanaklardan birini seçme edimi ve bu edimin sonucu"; karar verme ise, "karar birimlerinin belirlenmiş bir ya da daha fazla amaca ulaşmak için var olan çeşitli seçenekler arasında seçim yapmalarına yönelik davranış biçimi” olarak tanımlanmaktadır. (TDK Büyük Türkçe Sözlük, 2005) Karar verme kavramı, en basit şekilde, çok sayıdaki alternatifin değerlendirildiği ve aralarından optimal seçimin yapıldığı süreç olarak tanımlanabilir. K1saca, karar kavramı, bir neticeyi; karar verme kavramı ise, bu neticeye ulaşmayı sağlayan süreci ifade etmektedir.

Yaşamın her anında karşılaşılan karar verme olgusunu, Evren ve Ülengin (1992), "mevcut tüm alternatifler arasından araç veya amaçlara en uygun, mümkün bir veya birkaçını seçme süreci" olarak tanımlamaktadır.

Kuruüzüm (2000), karar verme kavramını, “sorunlar sistemini çözüme kavuşturmada, edinilen bilgilerin uygun karar modellerinde kullanılmasıyla üretilen alternatif davranış biçimlerinden birinin seçilmesi ve uygulanması" şeklinde ifade etmektedir.

Koçoğlu (2010) ise, "karşılaşılan durum ile ilgili olarak arzu edilen sonuçlara ulaşabilmek için yol gösterici bilgilerin toplanması, bu bilgiler 1şı̆̆ında sistematik, bilimsel ve mantıklı bir akıl yürütme ile seçenekler oluşturup bunların içinden en uygun olanının seçilerek uygulamaya konulması" şeklinde tanımlamaktadir.

\subsection{Karar Verme Eyleminin Özellikleri}

Karar verme durumu, yaşamın hemen her alanında ve safhasında sıklıkla karşılaşılan bir olgudur. Yaşam koşullarının sürekli olarak değişim ve gelişim içerisinde olmasıyla birlikte, karar verme süreci, daha da karmaşık ve güç bir hal almaktadır. Zorlaşan ve ağırlaşan günümüz koşullarında, karar vericinin, sadece tecrübe ve sezgilerine dayanarak hareket etmesi, sağlıklı ve doğru kararın verilebilmesi için yetersiz kalmaktadır. Bu noktada, karşılaşılan problemin çözümünde karar analizlerinin uygulanması, karar verici için önemli hale gelmektedir. "Karar analizi, karar verme sürecine sistematik ve analitik bir bakış açısı sunmaktadır. Bu bakış, problemdeki tüm ayrıntıları göz önüne almayı gerektirmektedir. Buna göre karar analizi, karmaşık bir karar probleminde mümkün olan tüm verinin toplanması, problemin ne olduğunun, hangi faktörlerden etkilendiğinin belirlenmesi ve olası tüm alternatiflerin ortaya konması ile mantık çerçevesi içinde probleme en iyi çözümü bulmayı amaçlayan nitel ve nicel yaklaşımların kullanılması olarak tanımlanmaktadır." (Lezki vd., 2016). Karar analizleri, doğru kararı vermekten ziyade iyi bir kararın verilmesini amaçlamaktadır. Bu noktada, iyi bir karar ile doğru bir kararın aynı kavramlar olmadığının belirtilmesi gerekmektedir. Bir 
problemin çözümünde, en iyi sonucu sağlayan karar, doğru karar olarak nitelendirilmektedir. Ancak, bir kararın sonuçlarının ne şekilde olacağı net olarak bilinemeyeceği için, bu kararın doğru mu yoksa yanlış mı olduğu, kararın uygulanmasından bir süre sonra saptanabilir. İyi karar olarak benimsenen alternatifin, aynı zamanda problemi çözüme ulaştıran doğru kararın olması beklenmektedir. Ancak, verilen bir kararın, doğru karar olarak tanımlanabilmesi için karar analizleri yapılırken ortaya konulan ön kabullerin doğruluğu ile çevresel etmenlerin gelecek zamanda alacağı boyutlarına ilişkin doğru tahminler yapılmalıdır. $\mathrm{Bu}$ bağlamda, verilen bir kararı belirlenen hedefe ulaştıracak "iyi bir karar", etkili, verimli, rasyonel, uygulanabilir ve zamanında alınmış olmalıdır. (Lezki vd., 2016).

\subsection{Karar Verme Eyleminin Bileşenleri}

Her bir karar verme eylemi, kendine özgü kavramlar, nitelikler ve bileşenler barındırmakla birlikte, genel bir değerlendirme yapıldığında karar verme eylemine dahil edilen temel bileşenler; karar verici, hedef ve ölçütler, alternatifler, karar matrisi, çevresel etmenler, olasılıklar, sonuçlar ve karar olarak sıralanmaktadir.

- Karar verici: Karar verme probleminin çözümlenebilmesi için belirlenen alternatifler arasından seçim yapan ve bu seçimin olumlu ya da olumsuz tüm sonuçlarının sorumluluğunu üstlenen kişi veya kişilerdir.

- Hedef: Karar, belirli bir hedefe yönelik olarak verilmektedir. Karşılaşılan problemin tanımlanması diğer bir deyişle, ulaşılmak istenilen hedefin belirlenmesi, karar verme probleminin çözümüne yönelik ilk adımdır. Karar verme sürecinin sağlıklı olarak yönetilebilmesi için hedefin net bir şekilde ortaya konulması gerekmektedir. Belirlenen hedef 1şı̆̆ında, karar problemi şekillendirilerek, hedefe hizmet edecek ölçüt ve alternatifler belirlenmektedir. Bu nedenle, karar verme problemini şekillendiren en kritik bileşenlerinden biri hedeftir.

- Ölçütler: Hedef ortaya konulduktan sonra ölçütlerin belirlenmesi ve ölçüt setlerinin oluşturulması gerekmektedir. Karar verme problemine dâhil edilen ölçütler, hedefe ulaşma noktasında karar alternatiflerinin doğru bir şekilde değerlendirilmesini sağlamaktadır. Karar verme sürecinde etkin rol oynayan karar ölçütleri belirlenirken özenle hareket edilmelidir.

- Alternatifler: Bir karar verme probleminin oluşabilmesi için en az iki alternatifin olması gerekmektedir. Alternatif, karar vericinin herhangi bir karar verme probleminin çözümünde izleyeceği yolları, tutumu, nesneleri ifade etmektedir. Alternatifler, karar verici tarafindan belirlenmektedir. Alternatiflerin karar verme problemini yansitabilecek doğrulukta ve sayıda olmasına özen gösterilmesi gerekmektedir. Çünkü karar verme sürecine dâhil edilmeyen alternatif veya alternatifler süreç sonunda fazladan maliyetlere neden olabilmektedir.

- Karar matrisi: Karar verme problemindeki ölçütlerin ve alternatiflerin bir arada gösterildiği matris ifadesidir.

- Çevresel etmenler: Karar verici tarafindan kontrol edilemeyen ve kararı önemli ölçüde etkileyen değişkenlerdir. Çevresel etmenler, gelecekte ortaya çıkması beklenilen ancak ne şekilde ortaya çıkacağı net olarak bilinemeyen durumlardır. Biyolojik, psikolojik, sosyolojik, ekonomik ve örgütsel etmenler bunlardan bazılarıdır.

- Olasılıklar: Karar verme problemindeki en kritik nokta, kararların gelecekle ilişkili olması ve geleceğin belirsizlik içermesidir. Bu belirsizlik durumuna ise, çevresel etmenler neden olmaktadır. Verilen kararı etkileyebilecek çevresel etmenlerin neler olacağı bilinebilir, ancak bunların gelecekte ne şekilde ortaya çıkacağı bilinemez. Bu nedenle, geçmişteki verilerden faydalanılarak gelecekte karşılaşılabilecek durumlara ilişkin tahminler yapılmaktadır. $\mathrm{Bu}$ tahminler, karar verme problemine, çevresel etmenlerin ortaya çıkma olasılıkları olarak yansımaktadır.

- Sonuçlar: Belirli bir alternatifin seçimi ve karar verme problemine dâhil edilen ölçütlerin etkisiyle ortaya çıkan değerlerdir. Her bir ölçüt ve alternatif ikilisi, matematiksel işlemlere tabi tutularak değerlendirilmekte ve sonuç değerleri sayısal değerlerle ifade edilmektedir. Sayısal değerlerle ifade edilemeyen karar verme problemlerinde ise, sonuç değerleri, fayda birimleri şeklinde göstermek mümkündür.

- Karar: Sonuçlar doğrultusunda genel bir değerlendirmenin yapılmasıyla elde edilen karar verme sürecinin çıktısıdır.

\subsection{Karar Verme Türleri}

Karar verme problemlerini; kararın verildiği ortam, yönetim kademesi, yapısı, bağlantılı olma durumu ve göz önünde bulundurulacak ölçüt bakımından sınıflandırılmak mümkündür..

\subsubsection{Verildiği Ortama Göre Kararlar}

Kararın verildiği ortam, karar verme probleminin çözümü için kullanılacak yaklaşımın belirlenmesinde etkilidir.

Karar verme ortamı, karar vericinin problem hakkında sahip olduğu bilgi seviyesiyle ilişkilidir. Özellikle, kararı etkileyen çevresel etmenler hakkında sahip olduğu bilgi düzeyi, kararın verildiği ortamın nasıl olduğu sorusu için büyük önem taşımaktadır. Verildiği ortama göre kararlar; belirlilik, belirsizlik ve risk ortamında verilen kararlar olarak sınıflandırılmaktadır.

- Belirlilik ortamında verilen karar: Herhangi bir karar verme sürecine ilişkin ölçüt, alternatif veya çevresel etmenlerin doğuracağı sonuçların önceden biliniyorsa, kararın belirlilik ortamında verildiği anlamına gelmektedir. Karar verme ortamında belirlilik durumu söz konusu olduğundan karar verme eylemi nispeten daha kolay olmaktadır. Bu tür karar verme problemlerinde, her bir ölçüt, alternatif ve değişkenin değerleri ve aralarındaki ilişkiler kesin olarak bilinmektedir.

- Belirsizlik ortamında verilen karar: Karar verme problemindeki ölçütler, alternatifler ve çevresel etmenler bilinmekle birlikte, hangi ölçütün veya alternatifin sonuca nasıl etki edeceği, hangi çevresel etmenin ne şekilde ve hangi olasılıkla ortaya çıkabileceği bilinmemektedir. Bu nedenle, belirsizlik ortamında verilen bir kararın taşıdığı riskin hesaplanması mümkün olamayacağından, karar matrisinde ifade edilen değerlere dayanılarak karar verilmektedir.

- Risk ortamında verilen karar: Bir karar verme probleminde yer alan ölçütlerin alabileceği değerler veya gerçekleşme olasılıkları biliniyorsa, benimsenen stratejiye bağlı olarak verilen kararın doğuracağı risklerin ölçülebildiği anlamına gelmektedir. Bu türden kararlar, risk ortamında verilen karar olarak tanımlanmaktadır. Söz konusu değerlerin veya olasılıkların bilinmesinin önemli avantajı, karar verici tarafından benimsenen alternatife göre elde edilmesi beklenen sonuç için ne ölçüde bir riskin alındığının hesaplanabilmesidir. 


\subsubsection{Yönetim Kademesine Göre Kararlar}

Yönetim kademesine göre kararlar; stratejik, taktiksel ve operasyonel kararlar olarak sinıflandırılmaktadır.

- Stratejik karar: "Üst yönetim tarafindan verilen kararlardır. Bu tür kararların özellikleri, kararın çok karmaşık bir yapıda olmas1, karar sonucunun etkilerinin uzun vadede ortaya çıkması, genellikle belirsizlik ortamında verilmesi, işletmenin varlığı ve devamlılığı açısından önemli etkilerinin olmasıdır. Bu tür kararlara yeni bir pazara girme, üretim teknolojilerinin seçimi, finansman politikalarının belirlenmesi örnek olarak verilebilir.” (Lezki vd., 2016).

- Taktiksel karar: "Bu tür kararlar orta düzey yönetim tarafindan verilen kararlardır. Stratejik kararların uygulanabilmesi amaciyla orta vadede yapılması gereken faaliyetlere ilişkin olup genel olarak risk ortamında verilen kararlardır. Yıllık bütçe planı, mevcut tedarikçilerle olan anlaşmaların yenilenmesi, yeni reklam kampanyasının nasıl olacağı bu tür karar örnekleridir.” (Lezki vd., 2016).

- Operasyonel karar: "Bu tür kararlar, alt yönetim kararları olup sonuçları kısa vadede ortaya çıkar. Günlük, haftalık ve aylık faaliyetlerin yerine getirilebilmesi için verilmesi gereken kararlardır ve belirlilik ortamında verilir. Günlük iş emirlerinin hazırlanması, haftalı üretim planının oluşturulması, aylık stok miktarının belirlenmesi operasyonel karar örnekleridir.” (Lezki vd., 2016).

\subsubsection{Yapılarına Göre Kararlar}

Yapılarına göre kararlar; yapılandırılmış (programlanabilir), yapılandırılmamış (programlanamayan) ve yarı yapılandırılmış (yarı programlanabilen) kararlar olarak sınıflandırılmaktadır.

- Yapılandırılmış (Programlanabilir) karar: "Bu tür kararlar, rutin olarak sık sık tekrarlanan kararlardır. Bu nedenle karar probleminin çözümüne ilişkin izlenecek yol, kullanılacak yöntemler önceden belirlenmiştir ve her defasında aynı yol ve yöntemleri kullanmak çözüm için yeterli olacaktır." (Lezki vd., 2016).

- Yapılandırılmamış (Programlanamayan) karar: "Bu tür kararlar, alışılmamış, daha önceden karşılaşılmamış ve tekrarlanmayan özgün nitelikteki kararlardır. Belirsizlik ortamı söz konusu olup karmaşıklık derecesi büyüktür. Bu tür kararlarda, ilk kez karşılaşıldığından çözüm için önceden belirlenmiş standart bir prosedür olmayıp nasıl bir yol ve yöntem izlenmesi gerektiği karar sürecinin başında bilinmemektedir. Bu nedenle çözüm için ayrıntılı karar analizine ihtiyaç duyulan kararlardır.” (Lezki vd., 2016).

- Yarı yapılandırılmış (Yarı programlanabilen) karar: "Bu kararlar, yapılandırılmış ve yapılandırılmamış karar türlerinin birleşimidir. Karar probleminin bir kısmı için önceden belirlenen standart prosedürler uygulanabilirken, problemin tamamen çözümü için yeterli olmamaktadır. Taktiksel karar grubunda yer almaktadır.” (Lezki vd., 2016).

\subsubsection{Bağlantılı Olma Durumuna Göre Kararlar}

Bağlantılı olma durumuna göre kararlar; tek aşamalı ve çok aşamalı kararlar olarak sınıflandırılmaktadır.

- Tek aşamalı karar: "Karar problemlerinin bir kısmı, tek bir kararın verilmesini gerektiren ve söz konusu kararın sonucuna bağlı olarak belirli bir katkının elde edildiği yapıdadır. Bu tip kararlarda verilen kararın sonucu başka kararları etkilemez ve dolayısıyla başka bir karar ile herhangi bir bağlantısı yoktur." (Lezki vd., 2016).

- Çok aşamalı karar: "Pek çok karar probleminde ise verilen bir kararın sonucu verilen ilk kararla aynı zamanda ya da daha sonraki bir zamanda verilecek başka kararları da etkilemektedir. Birbiriyle bağlantılı bir dizi kararın alınmasını gerektiren böylesi karar problemleri de çok aşamalı karar problemi olarak adlandırılır." (Lezki vd., 2016).

\subsubsection{Göz Önünde Bulundurulacak Ölçüt Açısından Kararlar}

Göz önünde bulundurulacak ölçüt açısından kararlar; tek ölçütlü ve çok ölçütlü kararlar olarak sınıflandırılmaktadır.

- $\quad$ Tek ölçütlü karar: "Karar probleminde ulaşılmak istenen tek bir amaç ve bu amaca ulaşabilmek için kullanılacak tek bir değerlendirme ölçütü olduğunda karar problemi tek ölçütlü karar problemidir." (Lezki vd., 2016)

- Çok ölçütlü karar: "Günümüzde bireysel kararlarda da işletme kararlarında da tek bir ölçütün göz önüne alındığ 1 karar problemlerinin sayısı oldukça azdır. Birden fazla niteliğin aynı anda en iyi değerleri alabilmesi çabası çok ölçütlü karar verme tekniklerinin geliştirilmesine neden olmuştur. Bunlardan en bilinenleri olan AHP, ANP, TOPSIS ve ELECTRE teknikleridir.” (Lezki vd., 2016).

\subsection{Karar Verme Yaklaşımları}

Karar verme eyleminde kullanılan yaklaşımlar arasındaki farklılıkların temelinde, karar verme probleminin yapısı ile karar vericinin tutum ve tercihleri yer almaktadır. Karar vericinin karar verme problemi hakkında sahip olduğu bilgi düzeyi, problem karşısındaki tutum ve davranışları, içerisinde bulunduğu psikolojik durum, karar verdiği ortamın niteliği, hedeflerini gerçekleştirme isteği/zorunluluğu gibi etmenler kullanacak yaklaşımın belirlemesinde önemli ölçüde etkili olmaktadır. Ele alınan karar verme probleminin niteliği, yapısı, önemi, problemdeki karar değişkenleri ve çevresel etmenler göz önünde bulundurularak belirlenen yaklaşım ile optimum seçim yapılmaktadır. Tüm bu ölçütler doğrultusunda karar verme yaklaşımları; sezgisel, deneyimsel ve bilimsel karar verme yaklaşımı olarak sınıflandırılmaktadır.

- Sezgisel karar verme yaklaşımı: Sezgisel karar verme yaklaşımında, karar verme problemiyle ilgili herhangi bir araştırma, veri toplama ve analiz yapma yöntemler kullanılmamaktadır. Analizler, karar vericinin sezgileri ve duygularına dayanılarak yapılmaktadır. Her bir karar verme probleminde yer alan ölçütlerin etki dereceleri farklı olduğuna göre, her karar verme probleminin de belli derecelerde riskleri bulunmaktadır. Bu sebeple, sezgisel karar verme yaklaşımında, karar vericinin risk karşısındaki tutumu oldukça önem hale gelmektedir.

- Deneyimsel karar verme yaklaşımı: Deneyimsel karar verme yaklaşımında, karar vericinin deneyimlerinden elde ettiği bilgilerden yararlanılmaktadır. Karar verme problemi, geçmişteki benzer durumların çözümünde izlenen yöntemle çözümlenmeye çalışılmaktadır. Karar verici, mevcut problem için bilimsel analizler yerine geçmiş durumlardan elde ettiği verilere dayanarak bir çözüme ulaşmaya çalışmaktadır.

- Bilimsel karar verme yaklaşımı: Deneyim, sezgi ve duygular, kararın verilmesinde oldukça önemli olmakla 
birlikte, her zaman yeterli olamayabilirler. Bilimsel karar verme yaklaşımında, karar verme problemleri analitik bakış açısıyla ele alınarak, uygun yöntemler aracılığıyla çözüme ulaşılmaktadır. $\mathrm{Bu}$ yaklaşımda, problemle ilgili bilgiler sistematik bir şekilde toplanmaktadır. Problemde yer alan kontrol edilen ve edilmeyen değişkenler ile problemdeki tüm etmenler arasındaki ilişkiler belirlenmektedir.

\section{Karar Verme Problemi ve Süreci}

Karar verme probleminin oluşabilmesi için, ortadan kaldırılması gereken bir durumun veya sorunun, belirli bir hedefe sahip olması ve bu hedefe ulaşılabilmesi için farklı sonuçlar veren karar verme alternatiflerinin bulunması gerekmektedir. Tek bir karar verme alternatifinin bulunduğu durumlarda, herhangi bir karar verme probleminin varlığından söz edilemez. Çünkü bu türden problemlerde, çözüm tektir ve mutlaka uygulanması gerekecektir. Karar verme eylemi, herhangi bir karar verme probleminin çözümünde birden fazla karar verme alternatifi içerisnden en iyi olanın seçilmesi şeklinde olabileceği gibi, ardışık karar verme alternatiflerinin çeşitli kombinasyonlarının içerisinden en iyisinin seçilmesiyle de yapilabilmektedir.

\subsection{Karar Verme Probleminin Özellikleri}

Her karar probleminin sahip olduğu risk, karmaşıklık, önem derecesi ve belirsizlik vb. faktörler birbirinden farklılık göstermekle birlikte, karar verme eyleminde genel olarak karşılaşılan temel özellikleri şu şekilde sıralamak olanaklıdır:

- Karar verme, gelecekle ilişkilidir.

- Karar verme, maddi ve manevi zorluklara sahiptir.

- Karar verme, zaman ve maliyet gerektirir.

- Karar verme, sorumluluk yükler.

- Karar verme, fazladan maliyetlere neden olabilir.

- Karar verme, rasyonellik ilkesine dayanır.

\subsection{Karar Verme Probleminin Modellenmesi}

Bilimsel karar verme yaklaşımı, karar verici tarafindan rasyonel, objektif ve bilinçli seçimlerin yapılabilmesi için sıklıkla başvurulan bir yöntemdir. Bu yaklaşımı tercih eden karar verici, karar verme probleminin tanımlanması ve çözümlenmesi için birtakım modellerden yararlanmaktadır. Model aracılığıyla, karmaşık yapılı bir karar verme probleminin daha anlaşılır hale getirilmesi amaçlanmaktadır. Karar verme problemlerinde kullanılan modeller; uyuşum (fiziksel), benzeşim (analog) ve sembolik (simgesel) olarak sinıflandırılmaktadır.

- Uyuşum modeli (Fiziksel model): "Temsil ettiği gerçek sistemle fiziksel ve niteliksel açıdan tam bir uyum hâlinde bulunan ve gerçek sistemin fiziksel olarak belirli ölçekte küçültülmüş ya da büyütülmüş olan örnekleridir." (Lezki vd., 2016).

- Benzeşim modeli (Analog model): "Gerçek sistemde var olan bir özelliğin modelde kolay anlaşılabilen başka bir özellikle temsil edildiği model türüdür." (Lezki vd., 2016).

- Sembolik model (Simgesel model): "İncelenen sistemin ya da durumun, harf, rakam ya da diğer semboller ve kavramlar yardımiyla temsil edilmesidir.” (Lezki vd., 2016).
Karar verme modeli ise, karar verme probleminin bir temsili olarak tanımlanabilir. Ulaşılmak istenilen hedef göz önünde bulundurularak, söz konusu karar verme problemindeki kontrol edilen ve edilmeyen değişkenler ile bu değişkenler arasındaki ilişkileri bir arada ortaya koyan ve çözüme en uygun alternatifin seçilebilmesini sağlayan modellerdir. Karar verme probleminin tanımlamasının akabinde, bir karar verme modeli oluşturularak en iyi çözüme ulaşma çabasına girilmektedir.

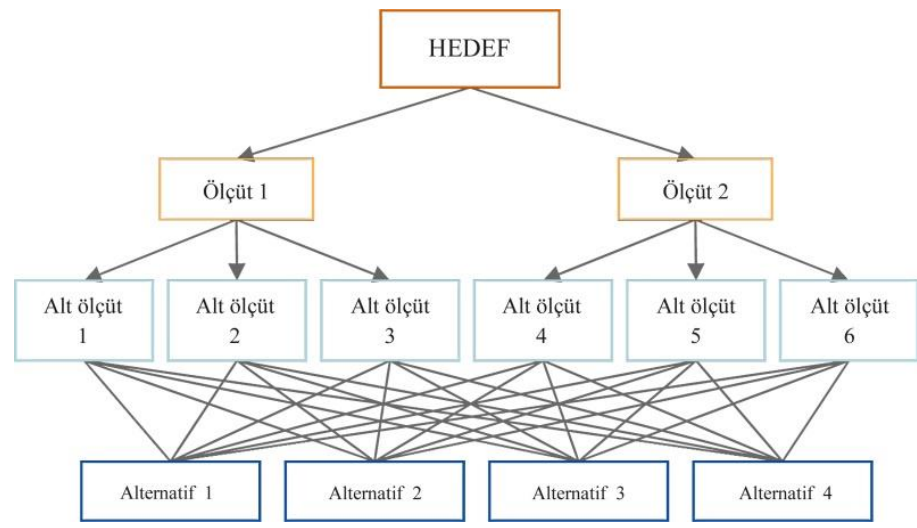

Şekil 1. Karar Verme Modeli Örneği (Figure 1. Decision-Making Model Example)

Bir karar verme probleminde, $\mathrm{A}_{1}, \mathrm{~A}_{2}, \ldots \mathrm{A}_{\mathrm{m}}$ ile ifade edilen $m$ sayıda alternatif ve $C_{1}, C_{2}, \ldots C_{n}$ ile ifade edilen $n$ sayıda farklı ölçütün olduğu varsayıldığında, her bir alternatif ve ölçüt ikilisi için $\mathrm{S}_{11}, \mathrm{~S}_{12}, \ldots \mathrm{S}_{\mathrm{mn}}$ ile ifade edilecek sonuç değerlerinin bulunduğu karar matrisi Tablo 1'de olduğu gibi gösterilmektedir. Kisaca, karar verme matrisinin satır kısmında birbirine olan üstünlüklerini gösterecek alternatifler, sütun kısmında ise karar verme eyleminde kullanılacak ölçütler yer almaktadır.

Tablo 1. Karar verme matrisinin genel yapısı ve bileşenleri (Lezki vd., 2016) (Table 1. General structure and components of the decision matrix (Lezki et al., 2016))

\begin{tabular}{l|cllllll}
\hline & \multicolumn{7}{|c}{ Ölçütler } \\
\hline Alternatifler & $\mathrm{C}_{1}$ & $\mathrm{C}_{2}$ & $\mathrm{C}_{3}$ &. &. &. & $\mathrm{C}_{\mathrm{n}}$ \\
\hline$A_{1}$ & $\mathrm{~S}_{11}$ & $\mathrm{~S}_{12}$ & $\mathrm{~S}_{13}$ &. &. &. & $\mathrm{~S}_{1 \mathrm{n}}$ \\
\hline$A_{2}$ & $\mathrm{~S}_{21}$ & $\mathrm{~S}_{22}$ & $\mathrm{~S}_{23}$ &. &. &. & $\mathrm{~S}_{2 \mathrm{n}}$ \\
\hline$A_{3}$ & $\mathrm{~S}_{31}$ & $\mathrm{~S}_{32}$ & $\mathrm{~S}_{33}$ &. &. &. & $\mathrm{~S}_{3 \mathrm{n}}$ \\
\hline$\cdot$ & $\ldots$ & $\ldots$ & $\ldots$ &. &. &. & $\ldots$ \\
$\cdot$ & $\ldots$ & $\ldots$ & $\ldots$ &. &. &. & $\ldots$ \\
. & $\ldots$ & $\ldots$ & $\ldots$ &. &. &. & $\ldots$ \\
\hline$A_{m}$ & $\mathrm{~S}_{\mathrm{m} 1}$ & $\mathrm{~S}_{\mathrm{m} 2}$ & $\mathrm{~S}_{\mathrm{m} 3}$ &. &. &. & $\mathrm{~S}_{\mathrm{mn}}$ \\
\hline
\end{tabular}

\subsection{Karar Verme Süreci}

Karar verme süreci, "herhangi bir kişinin herhangi bir durumla veya sorunla ilgili nasıl davranması gerektiği hakkında analitik bir tarzda düşündükten ve ilgili alternatifleri avantajları ve dezavantajları bakımından tarttıktan sonra, kendisi açısından en optimum uygulanabilirliğe ve faydaya sahip olan alternatifi seçme sürecidir." (Bayraktaroğlu ve Demir, 2011). Karar vermenin önemli bir safhasını oluşturan karar verme süreci bazı temel adımlardan oluşmaktadır. $\mathrm{Bu}$ sürecin; planlı olarak yürütülebilmesi, başarılı bir şekilde gerçekleştirilebilmesi ve etkin kararların alınabilmesi için bu sürece ilişkin bilinmesi gereken adimlar; 
- Karar verme probleminin tanımlanması,

- Ulaşılmak istenilen veya ulaşılması beklenilen hedefin belirlenmesi,

- Karar verme probleminin çözümlenebilmesi için gerekli verilerin toplanması,

- Karar ölçütlerinin ve alternatiflerin ortaya konulması,

- Alternatiflerin karar ölçütleri ve alt ölçütlerle birlikte değerlendirilmesi,

- Hedefe ulaştıracak en uygun alternatifin seçilmesi şeklinde özetlenebilir.

Son adım olarak, uygulamaya konulan alternatifin sonuçlarının izlenmesi ve değerlendirmelerin yapılması gerekmektedir. Bu adım ile birlikte, kararın ne ölçüde doğru ve etkin bir karar olduğu ortaya konulmaktadır. Ayrıca, uygulama sonrası duyarlılık analizinin yapılması, kararın etkililiğine fayda sağlayacaktır.

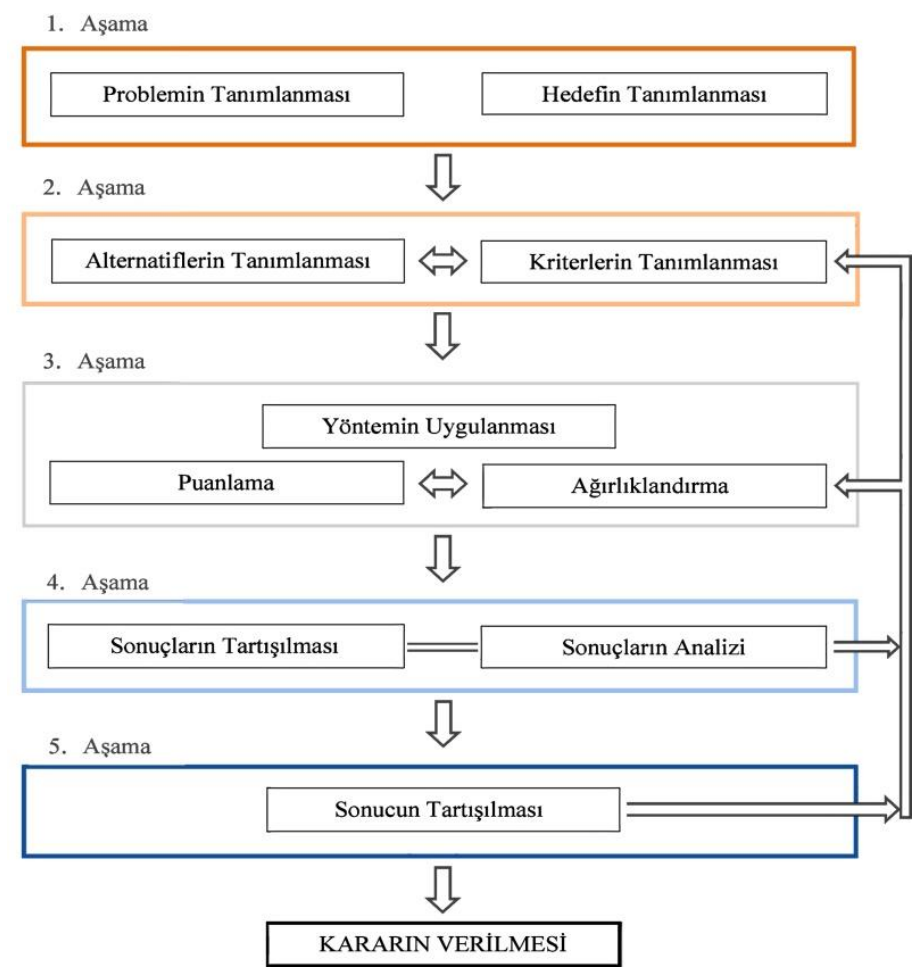

Şekil 2. Karar Verme Süreci (Recchia vd., 2011) (Figure 2. Decision-Making Process (Recchia et al., 2011))

\section{Sonuç}

Yaşamın hemen her aşamasında, yapılmakta olan veya yapılması planlanan çeşitli eylem ve olaylar ile ilgili çok sayıda alternatif arasından seçim yapmayı gerektiren durum veya problemlerle karşı karşıya kalınabilmektedir. Bu durum ve problemler, insanları çözüm bulmaya yöneltmekte; başka bir ifadeyle, seçim yapmaya zorlamaktadır. Birden fazla alternatifin oluşması durumuyla başlayan seçim süreci, belirli ölçütler çerçevesinde hedefe ulaştıran alternatiflerden bir veya birkaçının seçilmesiyle sonlanmaktadır. Bu seçim işlemi, "karar verme" eylemini en basit şekilde tanımlamaktadır. Karar verme, insan yaşamıyla oldukça iç içe geçmiş bir eylemdir. İnsanlar, zaman zaman farkında olmaksızın, istemsiz olarak karar vermektedir. Ancak, verilmesi gereken kararlar, her zaman basit, rutin, belirlilik içeren, üzerinde fazla düşünmeyi gerektirmeyen ve çözümlenmesi kolay olan türden olmayabilir. Bazı kararlar ise, çok daha karmaşık, belirsizlik içeren ve yüksek risk taşıyan yapidadir.
Kritik öneme sahip olan kararları vermeden önce, probleme ilişkin gerekli analizlerin yapılması ve bilgilerin toplanması gerekmektedir. $\mathrm{Bu}$ türden durumlarda, karar verici, çok sayıda alternatif arasından optimal olan seçimi yaparken birtakım yöntemler kullanabilir. Kararların karmaşıklığının ve önem düzeyinin artmasıyla karar vericinin üzerindeki baskı da artmakta; buna paralel olarak karar vericinin rolü daha da önem kazanmaktadır. Kararların karmaşıklığı, kararı etkileyen pek çok etkenin olmasından kaynaklanmaktadır. Kararların önem düzeyi ise, insan yaşamı üzerinde yapacağı olası değişikliklerle doğru orantılı olarak farklılaşmaktadır. Karar vericiler, lehte ve aleyhte olabilecek tüm olasılıkları göz önünde bulundurarak karar vermelidir. Aksi takdirde, verilen yanlış bir kararın sonuçlarının telafisi mümkün olmayabilir. Bu bağlamda, karar kuramının kavram ve tekniklerini bütünleştiren bilimsel yöntemlerin kullanılmasıyla daha doğru ve kesin karar vermek ve değerlendirmeler yapmak esas olmaktadır. Seçim yapmayı gerektiren bir durum veya problemle karşılaşıldığında, sağlıklı ve doğru kararların verilmesi, ancak etkin ve verimli karar verme yöntemlerinin uygulanmasıyla gerçekleştirilebilir. Karar verme probleminde birbiriyle çelişen hedeflerin yerine getirilmesi, birden fazla karar ölçütünün değerlendirilmesi ve çok sayıdaki alternatif arasından seçimin yapılması için karar verme yöntemlerinin kullanılması önerilmektedir. Karar kuramının ilkeleri ve yöntemlerinden faydalanılması, daha kolay, hızlı ve objektif karar verme imkânı sunarak kararın etkililiğine önemli kazanımlar sağlayacaktır. Karar vericinin kesin ifadelerle seçim yapabilmesini sağlayan karar verme yöntemlerinden yararlanılarak üstün verimli ve etkin alternatifin seçilmesi kolaylaşacaktır. Karar ölçütlerinin ve alternatiflerin sayısal değerlerle ifade edildiği karar verme yöntemlerinin kullanımı, problemin gerçeğe uygun verilerle çalışılmasına imkân tanıyarak, kararın verilmesinde ortaya çıkabilecek belirsizlikler ve olası hatalar önlenebilecektir. Bu faydalar göz önünde bulundurulduğunda, bütün değişken ve ölçütler dikkate alınarak rasyonel kararların alınmasını sağlayan karar verme yöntemlerinin kullanımı önemli bir potansiyel oluşturmaktadır.

\section{Kaynakça}

Adair, J. (2017). Karar Verme ve Problem Çözme (3. Baskı). İstanbul: Pegem Akademi.

Aladağ, Z. (2011). Karar Teorisi (2.bask1). İstanbul: Umuttepe.

Arslankaya, S. ve Göraltay, K. (2019). Çok Kriterli Karar Verme Yöntemlerinde Güncel Yaklaşımlar. Ankara: Iksad Publications

Bayraktaroğlu, S. ve Demir, K. (2011). İşyerinde Karar Verme ve Problem Çözme Yöntemleri. Ankara: İş ve Meslek Danışmanlığı Derneği Yayınları.

Ersever, H. Ö. (1996). Karar Verme Becerileri Kazandırma Programının ve Etkileşim Grubu Deneyiminin Üniversite Öğrencilerinin Karar Verme Stilleri Üzerindeki Etkileri. Ankara Üniversitesi, Sosyal Bilimler Enstitüsü, Doktora Tezi, Ankara.

Evren, R. ve Ülengin, F. (1992). Yönetimde Çok Amaçlı Karar Verme. İstanbul: İTÜ Yayınları.

Koçoğlu, E. (2010). İşletmelerde Yöneticilerin Karar Verme Süreci ve $\mathrm{Bu}$ Süreçte Bilişim Teknolojilerinin Kullanımı. Atılım Üniversitesi, Sosyal Bilimler Enstitüsü, Yüksek Lisans Tezi, Ankara.

Kuruüzüm, A. (2010). Karar Destek Sistemlerinde Çok Amaçlı Yöntemler. Antalya: Akdeniz Üniversitesi Basım Evi. 
Kuruüzüm, A. ve Atsan, N. (2001). Analitik Hiyerarşi Yöntemi ve İşletmecilik Alanındaki Uygulamaları. Akdeniz İ.İ.B.F. Dergisi, 1, ss. 83-105.

Lezki, Ş., Sönmez, H., Şıklar, E., Özdemir, A. ve Alptekin, N. (2016). İşletmelerde Karar Verme Teknikleri. Eskişehir: Anadolu Üniversitesi Yayınları.

Narasimhan, R. (1983). An Analytical Approach to Supplier Selection. Journal of Purchasing Materials Management, Winter, Vol. 19, No. 1, pp.27-32.

O'Brien, D. B. and Brugha, C. M. (2010). Adapting and Refining in Multi-Criteria Decision-Making. Journal of the Operational Research Society, 61(5), pp. 756-767.

Öz, E. ve Baykoç, Ö. F. (2004). Tedarikçi Seçimi Problemine Karar Teorisi Destekli Uzman Sistem Yaklaşımı. Gazi Üniversitesi Mühendislik- Mimarlık Fakültesi Dergisi, 19(3), ss. 275-286.

Recchia, L., Boncinelli, P., Cini, E., Vieri, M., Pegna, F. G., and Sarri, D. (2011). Multicriteria Analysis and LCA Techniques: With Applications to Agro-engineering Problems. London: Springer-Verlag.

Şişman M. (2013). Eğitimde Mükemmellik Arayışı Etkili Okullar. (4. Basım). Ankara: PegemA.

Temur, Ö. F. (2012). Öğretmen Algılarına Göre Yöneticilerin Karar Verme Stillerinin Öğretmenlerin Örgütsel Bağlllığına Etkisi: Rize İli Örneği. Recep Tayyip Erdoğan Üniversitesi Sosyal Bilimler Enstitüsü, Yüksek Lisans Tezi, Rize.

Tozlu, A. (2016). Karar Verme Yaklaşımları Üzerinde Herbert Simon Hegemonyası. Journal of Turkish Court of Accounts, 102 , ss. $27-45$.

Terzi, Ü., Hacaloğlu, S., E. ve Aladăg, Z. (2006). Otomobil Satın Alma Problemi İçin Bir Karar Destek Modeli. İstanbul Ticaret Üniversitesi Fen Bilimleri Dergisi, 5(10), ss. 43-49.

Türk Dil Kurumu. (2005). Büyük Türkçe Sözlük. Ankara: TDK Yayınları.

Türk Dil Kurumu. (2021). Güncel Türkçe Sözlük. Erişim adresi: https://sozluk.gov.tr/ (Erişim tarihi: 02.10.2021)

Türkşen, Ö. (2019). Çok Ölçütlü Karar Verme: Temel Kavramlar ve Tarihçe. Ankara Üniversitesi, Fen Fakültesi, İstatistik Bölümü (Ders Notu). Erişim adresi: https://acikders.ankara.edu.tr/pluginfile.php/105271/mod_re source/content/0/1.Temel\%20Kavramlar\%20ve\%20Tarihce. pdf (Erişim tarihi: 04.07.2021)

Tseng, Y. J. and Lin, Y. H. (2005), A Model for Supplier Selection and Tasks Assignment. Journal of American Academy of Business, 6(2), pp. 197-207.

Turan, G. (2015). Çok Kriterli Karar Verme Yöntemleri. Bursa: Dora Kitap.

Tzeng, G. H. and Huang, J. J. (2011). Multiple Attribute Decision Making: Methods and Applications. Boca Raton: CRC Press.

Yaralığlu, K. (2010). Karar Verme Yöntemleri. Ankara: Detay Yayıncilı.

Yıldırım, B. F. ve Önder, E. (2014). İşletmeciler, Mühendisler ve Yöneticiler için Operasyonel, Yönetsel ve Stratejik Problemlerin Çözümünde Çok Kriterli Karar Verme Yöntemleri. Bursa: Dora Yayınları. 